\title{
PENGARUH PENDAPATAN ASLI DAERAH, UKURAN PEMERINTAH DAERAH, TINGKAT KETERGANTUNGAN PEMERINTAH DAERAH TERHADAP TINGKAT PENGUNGKAPAN LAPORAN KEUANGAN PEMERINTAH DAERAH
}

\author{
Edo Anggara ${ }^{1}$, Charoline Cheisviyanny ${ }^{2}$ \\ ${ }^{1}$ Alumni Jurusan Akuntansi Fakultas Ekonomi, Universitas Negeri Padang \\ ${ }^{2}$ Jurusan Akuntansi Fakultas Ekonomi, Universitas Negeri Padang \\ *Korespondensi: edoanggara826@gmail.com
}

\begin{abstract}
This study aims to empirically show the effect of of original local government revenue on local government scope, the dependence level of local government and audit findings against financial statements disclosure of local government. The sample selection uses the total sampling method. Original local government revenue is measured by using the natural logarithm of regional revenue, local government scope is measured by total local government assets in LKPD, dependency level of local government is measured by fund transfers divided by total revenue, audit findings are measured from the results of audits of the Indonesian Supreme Audit Institution on the internal control system of government (BPK). This findings show that the level of local government dependency has positive effect on the level of financial statements disclosure in local government. The findings with the sig value of 0,000<0.05, and the calculated value of 3.785> tt table 2.006, it can be concluded that the H3 Hypothesis Accepted, and this study can contribute empirically by $28.91 \%$. Meanwhile, the original local government revenue on local government scope variable, size of local government and audit findings do not affect the level of financial statement disclosure. The suggestions for further research are expected to improve the number of research samples and observation year. Moreover, the other variables can be used to measure the level of disclosure, and the data analysis techniques is qualitative using interview method to obtain information about disclosure of financial statement.
\end{abstract}

Keywords: Local Goverment Revenue, Government Scope, Local Goverment Dependency Level, Audit Findings, Local Goverment Financial Statement

How to cite (APA $6^{\text {th }}$ style):

Anggara, E. \& Cheisviyanny, C. (2020). Pengaruh Pendapatan Asli Daerah, Ukuran Pemerintah Daerah, Tingkat Ketergantungan Pemerintah Daerah terhadap Tingkat Pengungkapan Laporan Keuangan Pemerintah Daerah. Jurnal Eksplorasi Akuntansi. 2(1), Seri B, 21622184.

\section{PENDAHULUAN}

Perkembangan teknologi informasi memacu suatu cara baru dalam kehidupan. Dikenal dengan E-life. kehidupan sudah dipengaruhi oleh berbagai kebutuhan secara elektronik. dan 
sekarang ini semarak dengan berbagai huruf yang dimulai dengan awalan E, seperti e-commerce, $e$ - education, e-library, e-journal, dan yang lain-lain berbasis elektronika. Perubahan sistem dan kemajuan teknologi juga berdampak pada pengelolaan sistem pada pemerintahan dari awalnya sentralisasi menjadi desentralisasi. Sehingga perubahan ini menyebabkan adanya perubahan sistem pertanggung jawaban pada pemerintah daerah dalam mengelola keuangan dari pemerintah pusat maupun ke pemerintah daerah.

Penggunaan teknologi informasi oleh pemerintahan, penggunaan internet dan intranet yang mempunyai kemampuan untuk menghubungkan keperluan penduduk, bisnis, dan kegiatan lainya bisa merupakan suatu proses transaksi bisnis antara publik dengan pemerintah melalui sistem informasi dan jaringan internet. yang lebih umum dikenal dengan world wide web. Pada dasarnya e-goverment adalah penggunaan teknologi informasi yang meningkatkan hubungan antara pemerintah dengan pihak-pihak lain. Perkembangan teknologi informasi telah mempengaruhi perkembangan perekonomian yang ditandai dengan proses digitalisasi pertukaran informasi melalui berbagai media komunikasi dan pemanfaatan teknologi informasi. Proses menggunakan teknologi informasi telah banyak memudahkan aktivitas entitas ekonomi yang sebelumnya dengan proses manual dan konvensional (Bonson dan Escobar, 2005 dalam puspita dan martani 2012) masyarakat membutuhkan akses informasi yang cepat, murah, dan mudah.

Salah satunya dengan menggunakan website. Pemerintah daerah juga menggunakan website sebagai salah satu sarana dalam penyampaian akuntabilitas pelaksanaan anggaran daerah kepada publik. Melalui website tersebut terpenuhi seluruh informasi yang dibutuhkan oleh institusi publik atas pelaporan keuangan pemerintah daerah adalah informasi kepatuhan terhadap aturan, informasi kinerja, informasi kondisi keuangan dan informasi perencanaan dan penganggaran. Tidak hanya itu, laporan keuangan pemerintah daerah yang dipublikasikan pad website juga harus berkualitas yakni relevan, andal, dapat dibandingkan, serta dapat di pahami oleh penggunanya. Pengungkapan informasi dalam laporan keuangan memiliki dampak ekonomis dan subtansial dalam pengambilan keputusan. Dalam pelaporan keuangan pemerintah daerah, baik pihak eksekutif maupun legislatif sama-sama berkepentingan untuk memastikan bahwa laporan keuangan pemerintah daerah telah memberikan penjelasan yang memadai mengenai kepatuhan terhadap aturan, informasi kinerja, informasi kondisi keuangan, serta informasi perencanaan dan penganggaran (Novia et.al, 2015)

Website pemerintah dapat digunakan sebagai salah satu sarana untuk menyampaikan akuntabilitas pelaksanaan anggaran dari pemerintah daerah kepada publik. Riset di beberapa negara, menunjukkan, salah satu bentuk transparansi dan akuntabilitas pemerintah daerah dilakukan dengan mempublikasikan laporan keuangan di internet (Laswad et.al, 2005). Penggunaan internet sebagai media penyampaian informasi keuangan daerah, telah dilakukan di New Zealand. Berdasarkan penelitian yang dilakukan oleh Laswad, Fisher \& Oyelere (2005), beberapa pemerintahan lokal di New Zealand memilih untuk menyediakan pengungkapan pelaporan keuangan di internet. Hasil penelitian atas pengungkapan dengan internet memberikan pengembangan akan kegiatan transparansi dan akuntabilitas terhadap pelaporan keuangan di New Zealand.

Beberapa peraturan di Indonesia juga telah menyebutkan secara implisit mengenai memanfaatkan media elektronik untuk mengungkapkan informasi kepada masyarakat. Peraturan tersebut diantaranya adalah PP No. 6 Tahun 2008, PP No. 3 Tahun 2007, dan Permendagri No. 7A Tahun 2007. Media elektronik pada ketiga peraturan yang dimaksud dapat merujuk kepada website milik Pemda yang dapat dimanfaatkan Pemda untuk mengungkapkan informasi kepada masyarakat. Informasi yang harus diungkapkan Pemda melalui media elektronik adalah: 
informasi laporan penyelenggaraan pemerintahan daerah (PP No. 3 Tahun 2007 dan Permendagri No. 7A Tahun 2007) dan hasil evaluasi penyelenggaraan pemerintahan daerah (PP No. 6 Tahun 2008).

Merujuk pada tiga peraturan tersebut, pengungkapan informasi selain informasi laporan penyelenggaraan pemerintahan daerah dan hasil evaluasi penyelenggaraan pemerintahan daerah dapat digolongkan sebagai pengungkapan yang bersifat sukarela. Kendati demikian menurut laporan Corruption Perceptions Index 2015, peringkat Indonesia baru menempati urutan 88 dari 168 negara yang diukur, dengan skor sebesar 36 dari total 100 poin maksimum (Transparency International, 2016). Hal ini menunjukkan perlunya upaya yang lebih serius dalam meningkatkan kualitas transparansi pemerintah dalam penyelenggaraan pemerintah.

Berdasarkan hasil survey yang dilakukan oleh Forum Indonesia Untuk Transparansi Anggaran (FITRA) pada September 2013 diungkapkan bahwa ternyata mayoritas Pemda di Indonesia (termasuk Sumatera Barat) masih enggan mempublikasikan pengelolaan anggaran pada situs resminya. Hal ini terlihat dari penelitian Agustin (2014) menemukan bahwa belum seluruh pemkab/pemkot di propinsi Sumatera Barat memanfaatkan menu transparansi pengelolaan anggaran (TPA) dalam website resmi pemerinta daerah untuk mempublikasikan secara lengkap dan konsisten jenis dokumen-dokumen terkait dengan penggunaan anggaran. Meskipun sebagian besar website Kabupaten di Sumatera Barat telah terdapat menu khusus/link bernama TPA (transparansi pengelolaan anggaran) untuk mendownload informasi atau dokumen keuangan dan kinerja tetapi menu khusus dan link tersebut terkadang kosong, tidak memuat secara lengkap, dan tidak dipublikasikan secara konsisten setiap tahunnya. Riset Agustin dan Arza (2019) juga menemukan anomali antara akuntabilitas dan transparansi publik terkait dengan manajemen pengelolaan keuangan daerah. Akuntabilitas publik telah meningkat dalam 7 tahun terakhir (2012-2019), dimana seluruh pemerintah kabupaten/kota di propinsi Sumatera Barat mempublikasikan pada website resmi maupun media massa setiap opini WTP dari BPK atas LKPD. Namun perilaku serupa tidak terjadi dalam konteks transparansi publik, dimana hampir setengah dari 19 pemerintah kabupaten/kota di propinsi Sumatera Barat yang bersedia mengungkapkan secara terbatas dokumen-dokumen terkait pengelolaan anggaran daerah (hanya 5-7 dokumen dari total 12 dokumen).

Fenomena tersebut mengindikasikan bahwa terdapat banyak faktor yang memengaruhi pengungkapan IFR pada website pemerintah. Website adalah sebagai media pengungkapan informasi mempunyai beberapa karakteristik dan keunggulan seperti mudah menyebar luas (prevasiveness), real-time, berbiaya rendah (low cost), dan mempunyai interaksi yang tinggi (hight interaction) (Ashbaugh et al. , 1999) website juga dapat mengintegrasikan teks, gambargambar bergerak,dan suara-suara (Debreceny et al. ,2002). Karakteristik yang lengkap tersebut membuat pemanfaatan website dapat dengan mudah diterima dan menjadi populer di kalangan masyarakat.

Beberapa penelitian terdahulu menunjukkan bahwa terdapat beberapa variabel yang menentukan pengungkapan sukarela di sektor publik. Penelitian Trisnawati dan Komarudin (2014) menunjukkan bahwa kompetisi politik, ukuran pemerintah daerah, rasio pembiayaan utang (leverage), dan kekayaan pemerintah daerah berpengaruh terhadap publikasi laporan keuangan pemerintah daerah. Kemudian riset Halmawati dan Nova (2014) pada SKPD di Kabupaten Sijunjung menemukan bahwa Peran internal audit berpengaruh positif terhadap kualitas laporan keuangan pemerintah daerah. Namun di sisi lain, komitmen karyawan serta pemahaman akuntansi justru tidak berpengaruh terhadap kualitas laporan keuangan. Sedangkan hasil penelitian Sinaga dan Prabowo (2011) menunjukkan hasil yang berlawanan dengan 
penelitian Trisnawati dan Komarudin, dimana hasilnya menunjukkan bahwa ukuran pemerintah daerah dan kekayaan daerah memiliki hubungan yang negatif dengan pelaporan keuangan melalui internet.

Dari hasil pengamatan, kedua penelitian ini juga memiliki kombinasi veriabel independen yang berbeda. Oleh karena itu, dipandang perlu untuk melakukan penelitian lebih lanjut untuk lebih menambah referensi atas faktor-faktor yang menentukan tingkat pelaporan akuntansi oleh pemerintah daerah, khususnya di Sumatera Barat yang memang belum banyak diteliti. Penelitian ini mengacu pada penelitian sebelumnya yang dilakukan oleh Trisnawati dan Komarudin (2014). Hasil penelitian Trisnawati dan komarudin (2014) menunjukkan bahwa kompetisi politik, ukuran pemerintah daerah, rasio pembiayaan hutang (leverage), dan kekayaan pemerintah daerah memiliki asosiasi terhadap pilihan dari pemerintah daerah untuk melaporkan informasi keuangannya di internet yang kemudian mendorong otoritas daerah untuk menjalankan pemerintahan dengan lebih transparan.

Alasan dipilihnya penelitian Trisnawati dan Komarudin (2014) sebagai acuan utama ialah bahwa dalam penelitian Trisnawati dan Komarudin telah mencakup variabel-variabel yang lebih kompleks dan beragam daripada penelitian sebelumnya. Hal yang membedakan penelitian ini dengan penelitian Trisnawati dan Komarudin (2014) ialah penelitian ini tidak menggunakan variabel rasio pembiayaan utang (leverage), kompetisi politik, tipe pemerintah daerah dan opini audit karena perbedaan demografi antar daerah yang menyebabkan ketersediaan data tidak mendukung, namun peneliti menambahkan dua variabel yaitu variabel kompleksitas pemerintah daerah dan belanja daerah yang diduga memiliki pengaruh terhadap pelaporan keuangan pemerintah daerah melalui internet.

Tujuan dari penelitian ini ialah Untuk menganalisa seberapa besar pemerintah daerah menjalankan transparansi pengelolaan keuangan daerah dengan melaporkan informasi keuangan pada situs pemerintah daerah, khusus nya pemerintah daerah kabupaten/kota di provinsi sumatera barat. Selain itu penelitian ini juga melihat pengaruh pendapatan asli daerah terhadap pengungkapan informasi keuangan pada website pemerintah daerah, pengaruh ukuran pemerintah daerah terhadap pengungkapan laporan keuangan pemerintah daerah, pengaruh dari ketergantungan terhadap pemerintah pusat terhadap pengungkapan laporan keuangan pemerintah daerah dan juga pengaruh dari temuan audit terhadap pengungkapan laporan keuangan pemerintah daerah pada website pemerintah daerah. Peneliti juga menyimpulkan bahwa pengungkapan laporan keuangan pemerintah daerah pada website pemerintah daerah juga dipengaruhi oleh banyak faktor maka dari itu penelitian ini berjudul "Pengaruh Pendapatan Asli Daerah, Ukuran Pemerintah Daerah, Tingkat Ketergantungan Pemerintah Daerah dan Temuan Audit Terhadap Tingkat Pengungkapan Laporan Keuangan Pemerintah Daerah”.

\section{REVIEW LITERATUR DAN PENGEMBANGAN HIPOTESIS Teori Stewardship}

Teori pertama yang mendasari penelitian ini dapat dijelaskan melalui perspektif teori (stewardship) dalam pemerintahan. Secara umum tujuan dari laporan keuangan adalah untuk memberikan informasi tentang posisi keuangan, kenerja dan arus kas yang bermanfaat bagi pengguna laporan keuangan dalam rangka membuat keputusan-keputusan ekonomi serta menunjukkan pertanggung jawaban pemerintah kepada publik mengenai laporan keuangan pemerintah. Stewardship selain itu, sebagai wujud dalam pencapaian good governace yang baik salah satunya berupa upaya pembuatan laporan keuangan. Agar hal tersebut dapat tercapai maka diperlukan suatu pengungkapan yang jelas mengenai data akuntansi dan informasi lainnya 
yang relevan. Teori utama terkait dengan tingkat pengungkapan laporan keuangan dan good governace ialah teori agency dan teori stewadship (Daniri, 2005). Dalam hubungan nya dengan sektor publik, teori yang akan digunakan dalam penelitian ini ialah teori stewardship. Apabila dalam teori agency menjelaskan tentang hubungan antara principal dan agent maka dalam teori stewardship menjelaskan tentang hubungan antara principal dan steward. Teori stewardship adalah teori yang menggambarkan situasi dimana para manajer tidak termotivasi oleh tujuantujuan individu seperti materi dan uang tetapi lebih ditujukan pada sasaran hasil utama mereka untuk kepentingan organisasi (Raharjo, 2007).

Teori ini mempunyai dasar psikologi dan sosiologi. Yang telah dirancang dimana para penerima amanah (steward) termotivasi untuk bertindak sesuai dengan keinginan pihak pemberi amanah (principal), selain itu perilaku steward tidak meninggalkan organisasinya. Dengan kata lain hubungan yang terjadi antara prinsipal dan steward dalam hal ini rakyat sebagai principal dan pemerintah sebagai steward, adalah hubungan yang terjain karena adanya sifat dasar manusia yang bisa dipercaya, mampu bertindak dengan penuh tanggung jawab, memiliki integritas, dan kejujuran terhadap pihak lain (Sari, 2007). Dengan adanya kesadaran seperti ini sebagai upaya dalam mengaktualisasi diri sebagai pegawai pemerintahan yang patuh maupun untuk mencapai tujuan pemerintahan yang bersih dan transparansi.

\section{Teori Keagenan (Agency Theory)}

Pada theory agency terdapat dua belah pihak yang melakukan kesepakatan kontrak. Yaitu pihak yang pertama adalah pihak yang memberikan kewenangan disebut dengan principal dan pihak yang kedua adalah sebagai pihak yang menerima kewenangan disebut dengan agent (Halim dan Abdullah, 2006) agency problem muncul ketika principal mendelegasikan kewenangan pengambilan keputusan pada agent (Zimmerman, 1977), hubungan keagenan ini menimbukan permasalahan, yaitu adanya informasi asimetris, dimana salah satu pihak mempunyai kewenangan informasi yang banyak dari pihak yang lainnya.

Zimmerman (1997) mengatakan bahwa masalah keagenan terjadi pada semua organisasi. Pada perusahaan agency problem terjadi karena pemegang saham sebagai principal dan manajemen sebagai agent, pada sektor pemerintahan. Agency problem terjadi antara pejabat pemerintahan yang terpilih dan diangkat sebagai (principal) dan para pemilih adalah (masyarakat) sebagai agent. Pejabat pemerintahan sebagai penyelenggaraan pelayanan publik yang memiliki informasi yang lebih sehingga dapat mengambil keputusan serta kebijakan yang hanya mementingkan pemerintahan dan kekuasaaan serta mengabaikan kepentingan dan kesejahteraan masyarakat.

Untuk mengurangi masalah tersebut pemerintah melakukan upaya yang harus dilakukan oleh pemerintah daerah adalah menyajikan laporan keuangan secara transparan dan akuntabel dalam pemerintahan. Eisenhardt (1989) menjelaskan bahwa teori keagenan menggunakan tiga asumsi sifat manusia. Pertama, asumsi tentang sifat manusia. Asumsi tentang sifat manusia menekankan bahwa manusia memiliki sifat untuk mementingkan diri sendiri (self interest), memiliki keterbatasan rasionalitas (bounded rationality), dan tidak menyukai risiko (risk aversion).

Menurut Lane (2003) teori keagenan dapat diterapkan pada organisasi sektor publik. Ia menyatakan bahwa negara demokrasi modern didasarkan pada serangkaian hubungan principalagent (Lane, 2000:13). Moe (1984) juga mengemukakan hal serupa mengenai konsep ekonomika organisasi sektor publik dengan menggunakan teori keagenan. Pernyataan ini mengandung arti bahwa dalam pengelolaan pemerintah daerah terdapat hubungan keagenan antara masyarakat 
sebagai principal dan pemerintah daerah sebagai agent yang mempunyai lebih banyak informasi. Teori keagenan memandang bahwa banyak terjadi asimetri informasi antara pihak agent yang mempunyai akses langsung terhadap informasi dengan pihak masyarakat. Adanya asimetri informasi inilah yang memungkinkan terjadinya penyelewengan atau korupsi oleh agent (Setiawan, 2012).

\section{Pengertian Pengungkapan Informasi Keuangan}

Kata disclosure memiliki arti tidak menutupi atau menyembunyikan. Apabila dikaitkan dengan data, disclosure berarti memberikan data yang bermanfaat kepada pihak yang memerlukan. Jadi data tersebut memang benar-benar bermanfaat bagi pihak yang membutuhkan. Karna apabila tidak bermanfaat, maka tujuan dari pengungkapan informasi keuangan tersebut tidak akan tercapai. Pengungkapan (disclosure) memiliki arti tidak menutupi atau tidak menyembunyikan. Hubungan nya dengan laporan keuangan, discloure memiliki arti bahwa laporan keuangan harus memberi informasi dan penjelasan yang lengkap mengenai hasil dari aktivitas pada suatu unit atau organisasi usaha (Chari dan Ghozali, 2000).

Salah satu komponen pokok dalam laporan keuangan pemerintah adalah catatan atas laporan keuangan (CaLK). Dalam PP Nomor 71 Tahun 2010 lampiran I.Catatan atas laporan keuangan meliputi penjelasan naratif atau rincian dari angka yang tertera dari Laporan Realisasi Anggaran, Laporan Perubahan SAL, Laporan operasional, Laporan Perubahan Ekuitas, Neraca, dan Laporan Arus Kas. Menurut "kerangka Dasar penyusunan dan Penyajian Laporan Keuangan" (IAI, 2002:4), tujuan pelaporan keuangan adalah memberikan informasi tentang posisi keuangan,kinerja dan arus kas perusahaan yang bermanfaat bagi sebagian besar kalangan pengguna laporan keuangan dalam rangka membuat keputusan-keputusan ekonomi serta menunjukan pertanggung jawaban (stewardship).

Pengungkapan informasi adalah pemberian informasi oleh perusahaan, baik yang positif maupun negatif, yang mungkin berpengaruh terhadap suatu keputusan investasi. Keputusan mengenai apa yang akan diungkapkan harus didasarkan pada tujuan dasar pelaporan keuangan. Jika tekanannya kepada para investor, maka salah satu tujuannya adalah penyajian informasi laporan keuangan yang dapat dilakukan perbandingan mengenai hasil-hasil yang diharapkan.

\section{Jenis-jenis Pengungkapan Informasi Keuangan}

Pengungkapan laporan keuangan dapat dilakukan dalam bentuk penjelasan mengenai kebijakan akuntansi yang ditempuh, kontingensi metode persediaan,jumlah saham yang beredar dan ukuran alternatif, misalnya pos-pos yang dicatat berdasarkan historical cost. Adapun jenis pengungkapan yang digunakan perusahaan untuk memberikan informasi kepada stackeholders berupa:

\section{Pengungkapan Wajib (Mandatory Disclosure)}

Pengungkapan ini merupakan pengungkapan informasi yang diharuskan oleh peraturan yang berlaku, dalam hal ini peraturan dikeluarkan oleh badan pengawas pasar Modal (Bapepam), namun sebelum dikeluarkan keputusan ketua Bapepam Nomor 38/PM/1996 mengenai laporan tahunan bahwa yang dimaksud dengan pengungkapan informasi dalam pelaporan tahunan adalah meliputi semua pengungkapan informasi dalam laporan keuangan.

\section{Pengungkapan Sukarela (Voluntary Disclosure)}

Pengungkapan sukarela adalah pengungkapan informasi perusahaan yang dilakukan secara sukarela oleh perusahaan tanpa diharuskan oleh peraturan yang berlaku atau pengungkapan 
melebihi dari yang diwajibkan. Perusahaan akan melakukan penguungkapan melebihi kewajiban pengungkapan minimal jika dalam pengungkapan semacam itu akan menurunkan biaya modalnya atau jika tidak ingin ketinggalan praktik-praktik pengungkapan yang kompetitif. Sebaliknya, perusahaan-perusahanan akan melakukan sedikit apabila mereka merasa pengungkapan keuangan akan menampakan rahasia kepada pesaing atau menampakkan sisi buruk perusahaan didepan berbagai pihak yang melihat. Dengan adanya pengungkapan suka rela ini maka upaya untuk berkomunikasi secara efektif dengan pembaca-pembaca asing, karena tidak adanya standar akuntansi di pelaporan yang diterima secara internasional.

\section{Tujuan dari Pengungkapan Laporan Keuangan}

Perusahaan besar pada umumnya baik pada perusahaan swasta maupun pada perusahaan pada pemerintahan menjadi sorotan oleh banyak pihak, baik dari masyarakat secara umum maupun pemerintah, perusahaan dengan ukuran yang lebih besar relatif diawasi oleh lembagalembaga pemerintah, sehingga mereka berupaya menyajikan pengungkapan yang lebih baik untuk dapat meminimalisir tekanan-tekanan pemerintah. Oleh karena itu, perusahaan besar tersebut dituntut untuk mengungkapan informasi yang lebih lengkap.

Adapun yang menjadi tujuan dari pengungkapan adalah sebagai berikut: Untuk menguraikan hal-hal yang diakui dan memberikan pengukuran yang relevan atas hal-hal tersebut diluar pengukuran yang digunakan dalam laporan keuangan. Untuk memberikan informasi yang akan membantu investor dan kreditor menilai resiko dan potensial dari hal-hal yang telah diakui dan tidak diakui. Untuk memberikan informasi mengenai arus kas keluar atau arus kas keluar pada masa depan. Untuk membantu investor menilai pengembalian dari investasi yang telah mereka berikan. Untuk memberikan informasi yang lebih penting yang memungkinkan para pengguna laporan keuangan untuk membandingkan dalam satu tahun dan diantara beberapa tahun.

\section{Manfaat dari Pengungkapan Laporan Keuangan}

Ada beberapa manfaat yang diberikan dari pengungkapan laporan keuangan pemerintah daerah diantaranya adalah: Manfaat bagi kepentingan perusahaan adalah dapat memperoleh biaya modal yang lebih rendah yang berkaitan dengan berkurangnya resiko informasi bagi investor dan kreditur. Dengan demikian investor dan kreditor bersedia membeli sekuritas dengan harga tinggi, akibat dari harga sekuritas yang tinggi tersebut biaya modal perusahaan akan menjadi semakin rendah.

Bagi investor pengungkapan bermanfaat untuk mengurangi informasi berupa pengurangan kesalahan pembuatan keputusan investasi. Sehingga investor menjadi lebih percaya kepada perusahaan yang memberikan pengungkapan secara lengkap, akibatna sekuritas perusahaan menjadi lebih menarik bagi banyak investor dan harganya akan naik. Bagi kepentingan nasional, yaitu berupa adanya biaya modal perusahaan yang rendah dan berkurangnya resiko informasi yang dihadapi investor. Dengan diperolehnya biaya modal yang lebih rendah oleh perusahaan, pertumbuhan ekonomi dapat meningkat, kesempatan kerja jadi semaki meluas, dan pada akhirnya standar kehidupan secara nasional akan meningkat pula. Dengan berkurangnya resiko informasi yang dihadapii investor, pasar modal menjadi likuid. Likuiditas pasar modal diperlukan oleh perekonomian nasional karena dapat membantu alokasi modal secara efektif. 


\section{Karakteristik Pemerintah Daerah}

Menurut Kamus Umum Bahasa Indonesia (2006), karakteristik adalah ciri-ciri khusus; mempunyai sifat khas (kekhususan) sesuai dengan perwatakan tertentu yang membedakan sesuatu (orang) dengan sesuatu yang lain. Dengan demikian, karakteristik pemerintah daerah merupakan ciri-ciri khusus yang melekat pada pemerintah daerah, menandai sebuah pemerintah daerah, dan membedakannya dengan pemerintah daerah lain.

Mutu dan luas pengungkapan laporan keuangan masing-masing berbeda. Perbedaan ini dapat terjadi karena karakteristik, kebijakan, budaya, filosofi manajemen masing-masing entitas juga berbeda (Wardhani, 2009). Karakteristik pemerintah daerah dapat menjelaskan kepatuhan pengungkapan wajib dalam Laporan Keuangan Pemerintah Daerah, sehingga karakteristik pemerintah daerah merupakan prediktor kepatuhan pengungkapan wajib.

Karakteristik pemerintah daerah dapat berupa ukuran daerah, kesejahteraan, functional differentation, umur daerah, latar belakang pendidikan kepala daerah, leverage daerah, dan intergovernmental revenue (Suhardjanto et al., 2010). Penelitian ini menggunakan size, kompleksitas daerah, dan belanja daerah yang diduga kuat memiliki pengaruh terhadap pengungkapan laporan keuangan dalam website pemerintah daerah (Rora, 2012).

\section{Pengertian Pendapatan Asli Daerah (PAD)}

Berdasarkan Undang-Undang Nomor 33 Tahun 2004 pasal 1 ayat 18 dijelaskan bahwa, "Pendapatan asli daerah adalah penerimaan yang diperoleh daerah dari sumber-sumber dalam wilayahnya sendiri yang dipungut berdasarkan peraturan daerah sesuai dengan peraturan perundang-undangan yang berlaku." Mardiasmo (2004: 125) mengemukakan bahwa, "Pendapatan asli daerah adalah penerimaan daerah dari sektor pajak daerah, retribusi daerah, hasil perusahaan milik daerah, hasil kekayaan daerah yang dipisahkan, dan lain-lain pendapatan asli daerah yang sah."

Dari beberapa definisi diatas dapat disimpulkan bahwa pendapatan asli daerah merupakan sumber keuangan daerah yang diperoleh dari pajak daerah, retribusi daerah, hasil pengelolaan kekayaan daerah yang dipisahkan, dan lain-lain pendapatan asli daerah lainnya yang dikelola oleh pemerintah daerah berdasarkan peraturan perundang-undangan yang berlaku. Pendapatan asli daerah menunjukkan efektifitas pemerintah daerah dalam mengelola potesi daerah untuk dijadikan sebagai pendapatan secara otonomi yang digunakan untuk kesejahteraan masyarakat.

Pendapatan asli daerah memiliki tingkat material yang membuat pemerintah daerah lebih memilih untuk membatasi akses informasi mengenai pendapatan asli daerah kepada masyarakat (Craven \& Marston, 1999). Penelitian sebelumnya yang dilakukan oleh Medina (2012) menyatakan bahwa pendapatan asli daerah memiliki pengaruh positif terhadap transparansi informasi keuangan pada website pemerintah daerah tersebut.

\section{Pengertian Ukuran Pemerintah Daerah}

Ukuran organisasi (size) merupakan salah satu elemen dari struktur organisasi (Patrick, 2007). Terdapat banyak bukti yang mendukung ide bahwa ukuran sebuah organisasi secara signifikan mempengaruhi struktur organisasi. Organisasi-organisasi besar lebih cendrung memilik banyak aturan dan ketentuan dari pada organisasi kecil (wikipedia.com, 2010). Dengan demikian, dapat ditarik sebuah logika bahwa organisasi besar akan lebih ketat dalam menerapkan aturan, salah satunya mengenai pengungkapan wajib akuntansinya. 


\section{Tingkat Ketergantungan Pada Pemerintah Pusat}

Tingkat ketergantungan pada pemerintah pusat yang merupakan jenis pendanaan daerah yang berasal dari pemerintah pusat atau provinsi. Oleh karena itu, pemerintah pusat maupun pemerintah ataupun pemerintah provinsi akan meminta pengungkapan yang lebih sebagai upaya untuk memonitori kinerja pemerintah daerah atas penggunaan dana tersebut. Penelitian Robbins dan Austin (1986) menemukan bahwa tingkat ketergantungan pemerintah kota berhubungan positif signifikan terhadap tingkat pengungkapan laporan keuangan pemerintah kota. Adanya ketergantungan yang besar memungkinkan pemerintah pusat untuk melakukan pembatasan operasi pemerintah daerah (kota) dan meminta pengungkapan lebih untuk memonitori kinerja pemerintah daerah (kota) dengan pembatasi operasi tersebut.

\section{Temuan Audit Informasi Keuangan}

Temuan audit oleh (BPK) terdiri dari pemeriksaan keuangan dalam kasus-kasus yang telah ditemukan oleh BPK dalam laporan keuangan pemerintah daerah atas pelanggaran yang telah dilakukan suatu daerah terhadap ketentuan pengadilan intern maupun terhadap ketentuan perundang-undangan yang telah ditetapkan, penelitian liestiani (2008), menemukan bahwa jumlah temuan audit BPK berkorelasi positif dan signifikan terhadap tingkat pengungkapan laporan keuangan pada pemerintah daerah baik pada kota/kabupaten. Sebab dengan adanya temuan audit ini, BPK akan meminta adanya koreksi dang tingkat pengungkapannya. Sehingga, semakin besar jumlah temuan audit maka akan semakin besar juga jumlah tambahan pengungkapan yang akan diminta oleh BPK dalam laporan keuangan.

\section{Penelitian Terdahulu}

Penelitian terkait voluntary disclosure pemerintah daerah melalui media internet telah banyak diteliti (Groff dan Pittman, 2004; Laswad et al., 2005; Styles dan Tennyson, 2007; Pitrowski dan Bartelli, 2010; Jorge et al., 2011). Reformasi keuangan sektor publik di Selandia Baru pada awal tahun 1999 mendorong penelitian tentang pengungkapan sukarela via internet yang dilakukan oleh Laswad et al. (2005).

Mereka meneliti 86 (delapan puluh enam) website pemerintah lokal Selandia Baru yang terdiri dari 12 pemerintah regional/provinsi, 15 pemerintah kota dan 59 district council. Tujuan dari penelitian mereka adalah untuk mengidentifikasi faktor-faktor yang mempengaruhi pengungkapan sukarela Internet Financial Reporting (IFR) diantara pemerintah lokal. Hasil dari penelitiannya menunjukkan leverage, kekayaan pemerintah lokal, press visibility, dan jenis/tipe council memiliki hubungan dengan praktek IFR pada pemerintah lokal Selandia Baru.

Stlyes dan Tennyson (2007) melakukan penelitian terhadap ketersediaan dan kemudahan dalam mengakses data keuangan pemerintah lokal pada internet. Mereka mengambil 300 sampel pemerintah daerah di Amerika Serikat dengan berbagai ukuran daerah. Hasil penelitiannya menunjukkan ketersediaan data keuangan berpengaruh terhadap ukuran daerah, tingkat pendapatan perkapita dan tingkat pengungkapan. Sementara itu populasi, pendapatan perkapita dan tingkat hutang berpengaruh positif terhadap aksebilitas atau kemudahan dalam mengakses data keuangan.

Rora (2010) menganilis tingkat pengungkapan sukarela pada situs resmi pemerintah daerah. Ia mengukur tingkat pengungkapan sukarela berdasarkan jumlah pengungkapan konten, presentasi pengungkapan dan total pengungkapan pada situs resmi pemerintah daerah. Sedangkan kinerja pemerintah, tingkat ketergantungan dan karakteristik pemerintah daerah merupakan faktor-faktor yang mempengaruhi pengungkapan sukarela. Hasilnya, dapat diketahui 
bahwa hanya tingkat ketergantungan daerah saja yang mempengaruhi tingkat pengungkapan pada konten situs.

Kadek et al. (2015) meneliti tentang pelaporan keuangan pemerintah daerah pada website pemda, khususnya pemerintah daerah kabupaten/kota di Bali tahun 2010-2013. Hasil penelitiannya menunjukkan kompleksitas pemerintahan, ukuran pemerintah daerah, kekayaan pemerintah daerah, dan belanja daerah berpengaruh positif dan signifikan terhadap pelaporan informasi keuangan dalam website pemerintah daerah.

\section{Pengaruh Pendapatan Asli Daerah Terhadap Laporan Keuangan Pemerintah Daerah}

Amalina (2014) menemukan bahwa PAD berpengaruh signifikan terhadap kinerja pemerintah, sementara itu penelitian puspita (2011) menyebutkan bahwa ratio PAD tidak berpengaruh terhadap tingkat pengungkapan. Semakin baik kinerja pemerintah semakin baik pula tingkat pengungkapan yang dilakukan. PAD merupakan salah satu pengukuran dari kekayaan suatau daerah. Maka semakin menunjukan semakin baik pula kinerja daerah tersebut. Maka akan semakin besar dorongan untuk memberikan informasi yang dibutuhkan (stake holders). Maka berdasarkan dari penjelasan diatas dapat diambil kesimpulan bahwa hipotesis dalam penelitian ini adalah sebagai berikut:

$\mathrm{H}_{1}$ : Kekayaan pemerintah daerah (PAD) berpengaruh positif terhadap tingkat pengungkapan laporan keuangan pada website pemerintah daerah.

\section{Pengaruh Ukuran Pemerintah Daerah Terhadap Pengungkapan Laporan Keuangan Pemerintah Daerah}

Ukuran pemerintah daerah menunjukan besar kecilnya pemerintah. Sesuai dengan pengukuran dalam penelitian laswad dkk (2005), ukuran pemerintahan dalam penelitian ini dinilai dari aset. Dengan demikian, ukuran pemerintah menggambarkan besar kecilnya pemerintah dapat dilihat dari tota aset yang dimiliki. Ukuran pemerintah menunjukkan seberapa besar suatu pemerintahan tersebut. Dari penjelasan diatas maka dapat diambil kesimpulan bahwa hipotesis dari penelitian ini adalah sebagai berikut:

$\mathrm{H}_{2}$ : Ukuran pemerintah daerah berpengaruh positif terhadap tingkat pengungkapan laporan keuangan pada website pemerintah daerah.

\section{Pengaruh Tingkat Ketergantungan Daerah Terhadap Pengungkapan Laporan Keuangan Pemerintah Daerah}

Liestani (2008), Martani dan Lestari (2010), menemukan bahwa terdapat hubungan signifikan antara tingkat ketergantungan terhadap tingkat pengungkapan. Semakin tinggi DAU yang diterima oleh pemerintah daerah, menunjukan tingkat ketergantungan yang besar terhadap sumber dana yang lain untuk membiayai aparaturnya. Pemerintah daerah memiliki tingkat ketergantungan yang tinggi terhadap sumber dana pemerintah pusat maka daerah tersebut memiliki tekanan untuk mengungkapkan informasi lebih banyak. Dari penjelasan diatas maka dapat diambil kesimpulan bahwa hipotesis dari penelitian ini adalah sebagai berikut:

$\mathrm{H}_{3}$ : Tingkat ketergantungan daerah berpengaruh positif terhadap tingkat pengungkapan laporan keuangan pada website pemerintah daerah. 


\section{Pengaruh Temuan Audit Terhadap Pengungkapan Laporan Keuangan Pemerintah Daerah}

Temuan audit adalah suatu penyelenggaraan terhadap ketentuan yang berlaku baik mengenai pengendalian internal maupun kepatuhan terhadap perundang-undangan yang ditemukan oleh auditor pada waktu pemeriksaan. Dengan kata lain temuan audit adalah suatu kondisi tidak sesuai dengan kriteria yang berlaku. Pada setiap pemeriksaan, auditor akan memberikan rekommendasi perbaikan terhadap temuan audit. Temuan dan rekomendasi tersebut akan dikomunikasikan dengan objek pemeriksaan agar dilakukan perbaikan dan koreksi.

Dengan adanya temuan maka BPK akan meminta adanya peningkatan pengungkapan dan koreksi. Sehingga, semakin besar temuan audit maka akan semakin besar tingkap pengungkapan yang akan dilakukan oleh pemerintah daerah. Penelitian Martani dan Liestani (2012) menemukan bahwa jumlah temuan audit berhubungan positif dan signifikan terhadap tingkat pengungkapan laporan keuangan peningkatan pengungkapan menunjukan adanya perbaikan kualitas laporan keuangan yang dilakukan oleh pemerintah daerah. Dari penjelasan diatas maka dapat diambil kesimpulan bahwa hipotesis dari penelitian ini adalah sebagai berikut:

$\mathrm{H}_{4}$ : Jumlah temuan audit berpengaruh positif terhadap tingkat pengungkapan laporan keuangan pada website pemerintah daerah

\section{Kerangka Konseptual}

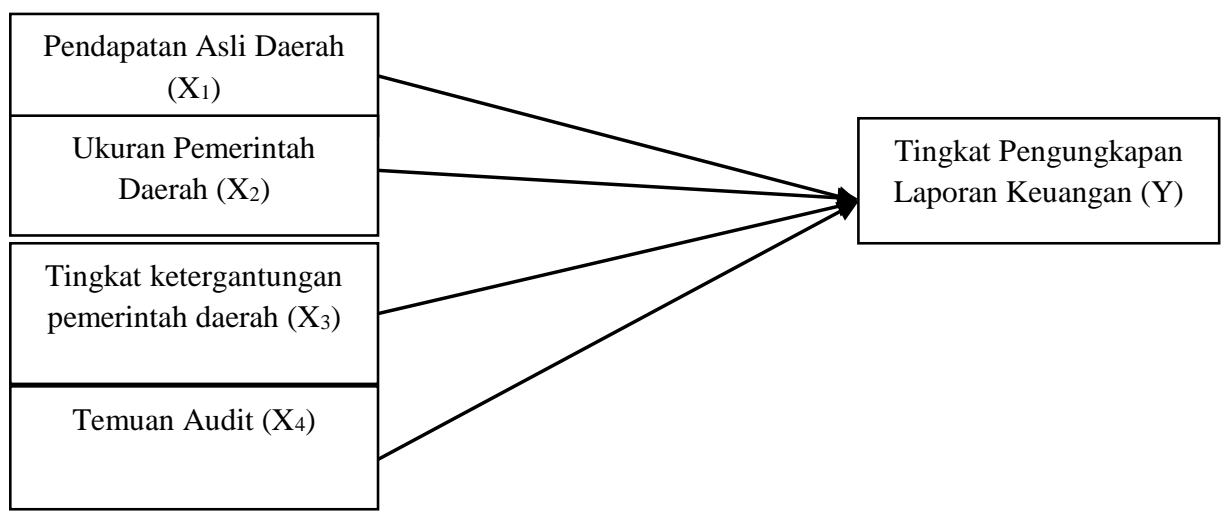

\section{Gambar 1 Kerangka Konseptual}

\section{METODE PENELITIAN}

Penelitian ini akan digunakan pendekatan kuantitatif untuk membuktikan secara empiris. Metode kuantitatif merupakan sebuah metode yang digunakan oleh banyak penelitian ilmiah sebagai bagian dari pengujian selain itu pendekatan ilmiah penelitian juga berguna untuk mencari tau sejauh mana pengaruh dari masing-masing variabel penelitian untuk dapat dilakukan ini dilakukan untuk memandang suatu realitas itu dapat diklasifikasikan, kongkrit, teramati, dan terukur, jika hubungan variabelnya bersifat sebab akibat dimana data penelitiannya berupa angka-angka dan analisisnya menggunakan statistik (Sugiyono, 2010).

Penelitian kuantitatif adalah penelitian yang bertujuan agar dapat memperoleh penjelasan dari suatu teori dan hukum-hukum realitas. Selain itu penelitian kuantitatif digunakan untuk mencari bukti empiris baru serta menjadi pengembangan dari penelitian sebelumnya, serta dapat membuktikan teori pendukung yang ada. 


\section{Populasi dan Sampel}

Populasi mengacu pada keseluruhan kelompok orang, kejadian atau suatu yang menarik untuk diteliti yang peneliti berniat untuk menelitinya (Sekaran, 2006). Populasi dalam penelitian ini adalah Kabupaten/Kota Se-Sumatera Barat. Metode yang digunakan dalam pengambilan sampel yakni secara Total Sampling, sehingga yang menjadi sampel dalam penelitian ini adalah seluruh kabupaten/kota di Provinsi sumatera barat.

\section{Jenis, Sumber dan Teknik Pengumpulan Data}

Jenis output data yang dipakai dalam penelitian ini yakni data dokumenter. Data dokumenter sendiri diperoleh dari beberapa sumber yang berupa LKPD serta LHP yang telah diterbitkan oleh badan pemeriksa keuangan. Laporan Hasil Pemeriksaan (LHP) yang dijadikan objek penelitian merupakan LHP (Laporan hasil pemeriksaan) yang telah di publikasikan di website Badan Pemeriksa Keuangan (BPK) atau diperoleh dari kantor perwakilan BPK (Badan Pemeriksa Keuangan) yang ada di masing-masing provinsi. Teknik analisis data yang digunakan dalam penelitian kuantitatif yakni Uji Regresi Berganda, Untuk melihat sejauh mana pengaruh antara variabel $\mathrm{X}_{1}, \mathrm{X}_{2}, \mathrm{X}_{3}, \mathrm{X}_{4}$ terhadap variabel $\mathrm{Y}$. Analisis regresi berganda terdiri dari uji asumsi klasik dan juga uji hipotesis kemudian dilakukan analisis secara deksriptif dari hasil olah data yang telah diperoleh Teknik Pengumpulan Data.

\section{HASIL DAN PEMBAHASAN \\ Deskriptif Variabel Penelitian}

Sebagaimana yang telah dijelaskan pada bagian pendahuluan, penelitian ini bertujuan untuk mengetahui seberapa besar pengaruh dari PAD Pemerintah daerah, Ukuran pemerintah daerah, tingkat ketergantungan pemerintah daerah serta temuan audit terhadap tingkat pengungkapan laporan keuangan pemerintah daerah.Populasi yang digunakan dalam penelitian ini adalah Laporan hasil pemeriksaan (LHP) Badan Pemeriksa Keuangan (BPK) Tahun 2015-2017 atas Laporan Keuangan Pemerintah Daerah (LKPD) yang diperoleh dari Kantor Badan Pemeriksa Keuangan (BPK) Cabang Padang.Teknik pemilihan sampel menggunakan metode Total Samplimg, sehingga diperoleh 57 Laporan Keuangan Pemerintah Daerah yang memenuhi kriteria untuk dijadikan sampel.

\section{Tingkat Pengungkapan Laporan Keuangan Pemerintah Daerah Dari Tahun 2015-2017}

Variabel dependen yang digunakan dalam penelitian ini adalah tingkat pengungkapan laporan keuangan pemerintah daerah yang diukur dengan menggunakan Tabel Checklist kriteria tingkat pengungkapan laporan keuangan pemerintah kabupaten dan kota berdasarkan dengan standar akuntansi pemerintahan yakni PP No. 71 Tahun 2010 yang diadaptasi dari penelitian sebelumnya Octasia (2018). Tingkat pengungkapan laporan keuangan pemerintah daerah diukur dengan membandingkan pengungkapan didalam laporan keuagan serta membuat checklist sesuai dengan peraturan standar serta memberikan skor 1 (satu) jika : Ya Diungkapkan dan 0 (Nol) Jika Tidak Diungkapkan. Dengan rincian rumus sebagai berikut:

$$
\text { Disclosure }=\frac{\text { Pengungkapan Dalam } L K P D}{\text { Pengungkapan dalam PSAP }}
$$


Metode ini juga dipakai dalam penelitian yang dilakukan oleh Hilmi, Martani, (2012), Setyaningrum dan Syafitri (2012). Hasil dari data merupakan gambaran dari proses tingkat pengungkapan laporan keuangan yang dilakukan. Data mengenai tingkat pengungkapan dapat dilihat pada tabel 1. Dari data diatas dapat dilihat bahwa untuk tahun 2015, pemerintah kabupaten pasaman merupakan pemerintah yang melakukan pengungkapan laporan keuangan paling tinggi yakni $0,74(74 \%)$ sedangkan pada tahun 2016 tingkat pengungkapan laporan keuangan paling tinggi oleh pemerintah kota payakumbuh yakni sebesar $0,74(74 \%)$ dan pada tahun 2017 diperoleh oleh kota padang dengan tingkat pengungkapan sebesar 0,74 (74\%).

\section{Tabel 1}

\section{Daftar Tingkat Pengungkapan}

Laporan Keuangan Pemerintah Daerah

\begin{tabular}{clccc}
\hline \multirow{2}{*}{ No } & & \multicolumn{3}{c}{ Variabel Y } \\
\cline { 3 - 5 } & & \multicolumn{3}{c}{ Tingkat Pengungkapan } \\
\cline { 3 - 5 } & & 0,60 & 0,64 & 0,72 \\
2 & Kahun 2015 & Tahun 2016 & Tahun 2017 \\
2 & Kabupaten Dharmasraya & 0,70 & 0,65 & 0,70 \\
3 & Kabupaten Kepulauan Mentawai & 0,71 & 0,68 & 0,71 \\
4 & Kabupaten Lima Puluh Kota & 0,70 & 0,67 & 0,66 \\
5 & Kabupaten Padang Pariaman & 0,68 & 0,68 & 0,62 \\
6 & Kabupaten Pasaman & 0,74 & 0,66 & 0,63 \\
7 & Kabupaten Pasaman Barat & 0,67 & 0,66 & 0,61 \\
8 & Kabupaten Pesisir Selatan & 0,70 & 0,71 & 0,59 \\
9 & Kabupaten Sijunjung & 0,68 & 0,63 & 0,62 \\
10 & Kabupaten Solok & 0,70 & 0,65 & 0,65 \\
11 & Kabupaten Solok Selatan & 0,63 & 0,68 & 0,65 \\
12 & Kabupaten Tanah Datar & 0,68 & 0,63 & 0,60 \\
13 & Kota Bukittinggi & 0,65 & 0,66 & 0,72 \\
14 & Kota Padang & 0,65 & 0,72 & 0,74 \\
15 & Kota Padang Panjang & 0,67 & 0,72 & 0,70 \\
16 & Kota Pariaman & 0,69 & 0,72 & 0,68 \\
17 & Kota Payakumbuh & 0,69 & 0,74 & 0,68 \\
18 & Kota Sawahlunto & 0,64 & 0,71 & 0,66 \\
19 & Kota Solok & 0,62 & 0,71 & 0,67 \\
\hline Sumber: Data sekunder yang diolah, Tahun & 2019 & & \\
& & & &
\end{tabular}

\section{Pendapatan Asli Daerah Terhadap Tingkat Pengungkapan Laporan Pemerintah Daerah}

Kekayaan pemerintah daerah dapat diukur dari jumlah Pendapatan asli daerah. Pendapatan asli daerah sendiri diukur dengan menggunakan logaritma natural (Ln PAD) dari total pendapatan asli daerah yang diterima pemerintah daerah setiap tahunnnya. Pendapatan asli daerah berasal dari pajak daerah, retribusi daerah, hasil pengelolaan kekayaan negara yang dipisahkan, dan lainlain pendapatan asli daerah yang sah. Hasil pengolahan data dari perhitungan pendapatan asli daerah (PAD) dapat dilihat pada tabel 2 sebagai berikut: 
Tabel 2

Data Hasil Perhitungan Pendapatan Asli Daerah (PAD)

\begin{tabular}{clccc}
\hline \multirow{2}{*}{ No } & & \multicolumn{3}{c}{ Variabel $\mathrm{X}_{1}$} \\
\cline { 3 - 5 } & & \multicolumn{3}{c}{ Pendapatan Asli Daerah $\left(\mathrm{X}_{1}\right)$} \\
\cline { 3 - 5 } & & Tahun 2015 & Tahun 2016 & Tahun 2017 \\
\hline 1 & Kabupaten Agam & 24,76 & 25,35 & 25,81 \\
2 & Kabupaten Dharmasraya & 24,48 & 24,46 & 25,32 \\
3 & Kabupaten Kepulauan Mentawai & 24,87 & 24,94 & 25,94 \\
4 & Kabupaten Lima Puluh Kota & 25,01 & 25,01 & 25,67 \\
5 & Kabupaten Padang Pariaman & 25,10 & 25,21 & 25,68 \\
6 & Kabupaten Pasaman & 24,96 & 25,24 & 25,79 \\
7 & Kabupaten Pasaman Barat & 25,41 & 25,41 & 25,91 \\
8 & Kabupaten Pesisir Selatan & 24,90 & 25,06 & 25,40 \\
9 & Kabupaten Sijunjung & 24,74 & 24,80 & 25,45 \\
10 & Kabupaten Solok & 24,44 & 24,66 & 25,05 \\
11 & Kabupaten Solok Selatan & 25,44 & 25,50 & 25,88 \\
12 & Kabupaten Tanah Datar & 24,91 & 24,99 & 25,35 \\
13 & Kota Bukittinggi & 26,64 & 26,69 & 27,03 \\
14 & Kota Padang & 24,93 & 24,98 & 25,21 \\
15 & Kota Padang Panjang & 24,12 & 24,11 & 24,15 \\
16 & Kota Pariaman & 25,33 & 25,19 & 25,48 \\
17 & Kota Payakumbuh & 24,68 & 24,70 & 24,86 \\
18 & Kota Sawahlunto & 24,32 & 24,46 & 24,46 \\
19 & Kota Solok & 474 & 476 & 483 \\
& Total Jumlah Pendapatan Asli Daerah & 24,96 & 25,03 & 25,42 \\
\hline & Rata-rata (Average) & & \\
\hline
\end{tabular}

Sumber: Data sekunder yang diolah, Tahun 2019

\section{Statistik Deskriptif}

Sebelum variabel penelitian dianalisis dengan pengujian rumus statistik, data dari masingmasing variabel penelitian dideskripsikan terlebih dahulu.Hal ini dimaksudkan agar dapat memberikan gambaran tentang masing-masing variabel yang diteliti. Data penelitian yang menjadi variabel dependen adalah Tingkat pengungkapan laporan keuangan pemerintah daerah (Y), sedangkan yang menjadi variabel independen adalah PAD Pemerintah Daerah $\left(\mathrm{X}_{1}\right)$, Ukuran pemerintah daerah $\left(\mathrm{X}_{2}\right)$, Tingkat ketergantungan pemerintah daerah pada pemerintah pusat, dan temuan audit yang dilakukan oleh Badan Pemeriksa Keuangan (BPK). Hasil analisis deskriptif dengan menggunakan Versi SPSS 23.0 dari variabel-variabel penelitian ini adalah sebagai berikut: 


\section{Tabel 3}

Statistik Deskriptif

\begin{tabular}{lrrrrr}
\hline \multicolumn{7}{c}{ Descriptive Statistics } \\
\hline & N & Minimum & Maximum & Mean & Std. \\
& Deviation \\
\hline PAD Pemerintah Daerah & 57 & 2411.00 & 2703.00 & 2513.5789 & 59.09978 \\
Ukuran Pemerintah Daerah & 57 & 2719.00 & 2959.00 & 2805.5088 & 45.78799 \\
Tingkat Ketergantungan Pemerintah & 57 & 78.00 & 95.00 & 90.2807 & 3.65843 \\
Pusat & 57 & 4 & 22 & 12.68 & 4.154 \\
Temuan Audit & 57 & 59.00 & 74.00 & 67.2456 & 3.78569 \\
Tingkat Pengungkapan & 57 & & & & \\
Valid N (listwise) & & & & &
\end{tabular}

Sumber: Data hasil olahan SPSS, Tahun 2019

Berdasarkan tabel diatas, PAD Pemerintah daerah sebagai variabel $\mathrm{X}_{1}$ mempunyai nilai minimum sebesar 2411 sedangkan nilai tertinggi pada 2703, dengan rata-rata sebesar 2513,58 dengan tingkat standar deviasi sebesar 59.100. untuk variabel $\mathrm{X}_{2}$ adalah variabel ukuran pemerintah daerah mempunyai nilai minimum sebesar 2719 sedangkan untuk nilai maksimum terbesar sebesar 2959, dengan nilai mean sebesar 2805,51 dengan standar deviasinya 45,788.

Untuk variabel $\mathrm{X}_{3}$ yakni tingkat ketergantungan pemerintah daerah kepada pemerintah pusat memiliki nilai minimum sebesar 78 (78\%) sedangkan nilai maximum sebesar 95 (95\%) dengan nilai tengah sebesar 90,28 yang memiliki standar deviasi sebesar 3.658. Variabel $\left(\mathrm{X}_{4}\right)$ terkahir dalam penelitian ini adalah temuan audit, temuan audit memiliki nilai minimum yakni 4 (empat) dengan nilai maksimum sebesar 22 (dua puluh dua temuan).

\section{Uji Multikolinearitas}

Uji multikolinearitas merupakan pengujian yang dilakukan untuk melihat suatu model penelitian apakah terjadi hubungan yang sempurna antara variabel bebas, sehingga sulit untuk memisahkan pengaruh antara variabel-variabel tersebut secara individu terhadap variabel terikat. Dasar dari pengambilan keputusan dalam uji multikolinearitas dengan melihat nilai Tolerance dari hasil data SPSS yang telah diolah dimana: Jika hasil nilai tolerance > (lebih besar) dari 0,10 maka dapat diambil artikan bahwa tidak terjadi multikolinearitas. Dapat juga menggunakan nilai VIF, dimana jika nilai VIF < lebih kecil dari 10,00 maka dapat diambil kesimpulan bahwa tidak terjadi gejala Multikolinearitas. Hasil dari Uji Multikolinearitas akan ditampilkan pada bagian ini kemudian akan diambil kesimpulan dari data yang ada.

Dari data yang ada pada Tabel 4.7 diatas dapat diambil kesimpulan bahwa dari variabel PAD pemerintah daerah mempunyai nilai tolerance 0,374 lebih besar > dari 0,10 maka dapat dikatakan tidak terjadi gejala multikolinearitas. Sedangkan dari data yang ada juga dapat dilihat Ukuran pemerintah daerah juga mempunyai nilai tolerance 0,478 lebih besar > dari 0,10 maka dikatakan tidak terjadi multikolinearitas, seihingga model regresi dapat lanjut untuk dilakukan peneltian. 


\section{Tabel 4}

Uji Multikolinearitas

\begin{tabular}{|c|c|c|c|c|c|c|c|c|}
\hline \multicolumn{9}{|c|}{ Coefficients $^{\mathrm{a}}$} \\
\hline & & \multicolumn{2}{|c|}{$\begin{array}{l}\text { Unstandardized } \\
\text { Coefficients }\end{array}$} & \multicolumn{2}{|l|}{$\begin{array}{l}\text { Standardized } \\
\text { Coefficients }\end{array}$} & & \multicolumn{2}{|c|}{$\begin{array}{l}\text { Collinearity } \\
\text { Statistics }\end{array}$} \\
\hline \multicolumn{2}{|c|}{ Model } & & $\begin{array}{l}\text { Std. } \\
\text { Error }\end{array}$ & Beta & $\mathrm{t}$ & Sig. & Tolerance & VIF \\
\hline 1 & (Constant) & 123.014 & 41.247 & & 2.982 & .004 & & \\
\hline & $\begin{array}{l}\text { PAD Pemerintah } \\
\text { Daerah }\end{array}$ & -.025 & .014 & -.398 & 1.879 & .066 & .374 & 2.676 \\
\hline & $\begin{array}{l}\text { Ukuran Pemerintah } \\
\text { Daerah }\end{array}$ & .013 & .015 & .163 & .870 & .388 & .478 & 2.092 \\
\hline & $\begin{array}{l}\text { Tingkat } \\
\text { Ketergantungan } \\
\text { Pemerintah Pusat }\end{array}$ & -.345 & .168 & -.333 & $2.051^{-}$ & .045 & .635 & 1.575 \\
\hline & Temuan Audit & .130 & .123 & .142 & 1.053 & .297 & .919 & 1.089 \\
\hline
\end{tabular}

Sumber: Data hasil olahan SPSS, Tahun 2019

Data diatas juga menampilkan bahwa Tingkat ketergantungan pemerintah daerah dengan pemerintah pusat memiliki nilai tolerance sebesar 0,635 atau lebih besar > dari 0,10 maka dapat diambil kesimpulan bahwa tidak terjadi multikolinearitas terhadap variabel tingkat ketergantungan. Untuk data yang dihasilkan menjelaskan bahwa temuan audit memiliki nilai tolerance 0,919, dengan kata lain lebih besar dari > 0,10 maka artinya tidak terjadi gejala multikolinearitas

\section{Uji Autokorelasi}

Uji Autokorelasi merupakan uji yang digunakan untuk mengetahui ada atau tidaknya penyimpangan asumsi klasik autokorelasi yaitu korelasi antara residual suatu pengamatan dengan pengamatan lain pada model regresi. Metode penelitian yang sering digunakan adalah uji Durbin-Watson (Uji DW) dengan ketentuan sebagai berikut:

\begin{tabular}{|c|c|c|c|c|c|}
\hline \multicolumn{6}{|c|}{$\begin{array}{c}\text { Tabel } 5 \\
\text { Uji Autokorelasi } \\
\text { Model Summary }^{\mathbf{b}} \\
\end{array}$} \\
\hline $\begin{array}{l}\text { Mode } \\
\text { I }\end{array}$ & $\mathrm{R}$ & R Square & $\begin{array}{l}\text { Adjusted R } \\
\text { Square }\end{array}$ & $\begin{array}{l}\text { Std. Error of } \\
\text { the Estimate }\end{array}$ & $\begin{array}{l}\text { Durbin- } \\
\text { Watson }\end{array}$ \\
\hline 1 & $.270^{\mathrm{a}}$ & .073 & .000 & 3.24037 & 1.902 \\
\hline
\end{tabular}

Berdasarkan tabel 4.8 hasil olahan data SPSS menunjukkan bahwa nilai durbin-watson dilambangkan dengan $\mathrm{d}=1,902 \mathrm{dl}=1,4264$ nilai $\mathrm{du}=1,7253$ nilai dari $4-\mathrm{dL}=2,5736$ serta nilai 4-dU $=2,2747$, nilai dl diperoleh dari tabel durbin watson,maka dapat disimpulkan bahwa dalam penelitian ini tidak terjadi autokorelasi antar variabel dikarenakan hasil olah data $\mathrm{dU}<\mathrm{d}<4$-dU, yakni $1,7253<1,902<2,2747$. 


\section{Uji Heterokedastisitas}

Uji heteroskedastisitas bertujuan untuk menguji apakah dalam sebuah model regresi terjadi ketidaksamaan varians dari residual atas satu pengamatan ke pengamatan yang lain. Jika varians dari residual suatu pengamatan ke pengamatan lain tetap, maka disebut homoskedastisitas dan jika berbeda disebut heteroskedastisitas. Penelitian ini menggunakan uji Glejser untuk mendeteksi adanya heteroskedastisitas. Apabila sig $>0,05$ pada uji ini, maka tidak terdapat gejala heterokedastisitas. Adapun hasil pengujian dapat dilihat pada tabel berikut:

\section{Tabel 6}

Uji Heteroskedastisitas

\begin{tabular}{|c|c|c|c|c|c|c|}
\hline \multicolumn{7}{|c|}{ Coefficients $^{\mathrm{a}}$} \\
\hline & & \multirow{3}{*}{\multicolumn{2}{|c|}{$\begin{array}{c}\text { Unstandardized } \\
\text { Coefficients } \\
\text { Std. }\end{array}$}} & \multirow{3}{*}{\multicolumn{3}{|c|}{$\begin{array}{l}\text { Standardized } \\
\text { Coefficients }\end{array}$}} \\
\hline & & & & & & \\
\hline & & & & & & \\
\hline \multicolumn{2}{|c|}{ Model } & B & Error & Beta & $\mathrm{t}$ & Sig. \\
\hline \multirow[t]{5}{*}{1} & (Constant) & .775 & 21.259 & & .036 & .971 \\
\hline & PAD Pemerintah Daerah & .013 & .007 & .406 & 1.877 & .066 \\
\hline & Ukuran Pemerintah Daerah & -.011 & .008 & -.267 & $1.398^{-}$ & .168 \\
\hline & Tingkat Ketergantungan Pemerintah Pusat & .012 & .087 & .023 & .139 & .890 \\
\hline & Temuan Audit & -.049 & .063 & -.106 & -.767 & .446 \\
\hline
\end{tabular}

Sumber: Data hasil olahan SPSS, Tahun 2019

Berdasarkan tabel diatas mengenai hasil olahan data dari program spss diketahu nilai sig PAD Pemerintah daerah $\left(\mathrm{X}_{1}\right)>$ dari 0,05 yaitu sebesar 0,066 sedangkan untuk variabel ukuran pemerintah daerah $\left(\mathrm{X}_{2}\right)>$ dari 0,05 yaitu sebesar 0,168 , variabel tingkat ketergantungan pemerintah daerah terhadap pemerintah pusat $\left(\mathrm{X}_{3}\right)>$ dari 0,05 yaitu 0,890 serta variabel independen temuan audit $\left(\mathrm{X}_{4}\right)>$ dari 0,05 yaitu sebesar 0,446. Maka dapat disimpulkan bahwa model regresi antara PAD pemerintah daerah, ukuran pemerintah daerah, tingkat ketergantungan pemerintah daerah terhadap pemerintah pusat, dan temuan audit terhdap tingkat pengungkapan laporan keuangan pemerintah daerah tidak terjadi masalah heteroskedastisitas.

\section{Uji Koefisien Determinasi}

Uji koefisien determinasi digunakan untuk dapat melihat seberapa besar pengaruh dari keempat variabel independen dalam membuktikan secara empiris hasil dari penelitian. Menurut Ghozali (2005). Nilai koefisien determinasi adalah antara nol dan satu. Jika nilai $R^{2}$ semakin mendekati model penelitian maka akan semakin baik. Hasil uji koefisien determinasi dapat pada:

\section{Tabel 7}

\section{Uji Koefisien Determinasi $\left(R^{2}\right)$} Model Summary

\begin{tabular}{lcccc}
\hline $\begin{array}{l}\text { Mod } \\
\text { el }\end{array}$ & $\mathrm{R}$ & $\mathrm{R}$ Square & $\begin{array}{c}\text { Adjusted R } \\
\text { Square }\end{array}$ & $\begin{array}{l}\text { Std. Error of } \\
\text { the Estimate }\end{array}$ \\
\hline 1 & $.358^{\mathrm{a}}$ & .128 & .061 & 3.66814 \\
\hline a. Predictors: (Constant), Temuan Audit, PAD Pemerintah Daerah, \\
Tingkat Ketergantungan Pemerintah Pusat, Ukuran Pemerintah \\
Daerah \\
Sumber: Data hasil olahan SPSS, Tahun 2019
\end{tabular}


Berdasarkan hasil output pengolahan data melalui program SPSS diatas, diketahui bahwa nilai R Square pada model summary sebesar 0,061 (6,1\%) nilai yang digunakan merupakan nilai dari Adjusted R Square maka dapat diambil kesimpulan bahwa penelitian ini membuktikan secara empiris atau dapat dikatakan berkontribusi sebesar 6,1\% mengenai Pengaruh antara PAD Pemerintah daerah, Ukuran pemerintah daerah, Tingkat ketergantungan pemerintah daerah terhadap pemerintah pusat, dan temuan audit terhadap tingkat pengungkapan laporan keuangan pemerintah daerah. Hal ini menujukkan bahwa masih rendah nya bukti empiris yang mendukung penelitian. Sisa nya sebesar 93,9\% dapat dikatakan dipengaruhi oleh faktor lain yang tidak diteliti dalam penelitian ini diantaranya adalah: Struktur pemerintah daerah, Kualitas Pengungakapan, Gaya kepemimpinan kepala daerah, tingkat hutang, rasio kinerja, serta opini audit.

\section{Analisis Data}

\section{Hasil Analisis Regresi}

Teknik analisis regresi berganda digunakan untuk mengetahui besarnya perubahan variabel terikat yang disebabkan oleh perubahan yang terjadi variabel bebas. Atau dapat mengetahui pengaruh masing-masing dari variabel bebas terhadap variabel terikat (dependen).

\section{Tabel 8}

Koefisien Regresi Berganda

\begin{tabular}{|c|c|c|c|c|c|c|}
\hline \multicolumn{7}{|c|}{ Coefficients $^{\mathbf{a}}$} \\
\hline & & \multicolumn{2}{|c|}{$\begin{array}{c}\text { Unstandardized } \\
\text { Coefficients }\end{array}$} & \multirow{2}{*}{$\begin{array}{c}\text { Standardized } \\
\text { Coefficients } \\
\text { Beta } \\
\end{array}$} & \multirow[b]{2}{*}{$\mathrm{t}$} & \multirow[b]{2}{*}{ Sig. } \\
\hline \multicolumn{2}{|c|}{ Model } & B & $\begin{array}{l}\text { Std. } \\
\text { Error }\end{array}$ & & & \\
\hline & (Constant) & 123.014 & 41.247 & & 2.982 & .004 \\
\hline & PAD Pemerintah Daerah & -.025 & .014 & -.398 & -1.879 & .066 \\
\hline & Ukuran Pemerintah Daerah & .013 & .015 & .163 & .870 & .388 \\
\hline & $\begin{array}{l}\text { Tingkat Ketergantungan Pemerintah } \\
\text { Pusat }\end{array}$ & -.345 & .168 & -.333 & 2.051 & .045 \\
\hline & Temuan Audit & .130 & .123 & .142 & 1.053 & .297 \\
\hline
\end{tabular}

a. Dependent Variable: Tingkat Pengungkapan

Sumber: Data hasil olahan SPSS, Tahun 2019

\section{Uji Hipotesis (T-test)}

Uji hipotesis digunakan untuk mengetahui secara masing-masing pengaruh dari variabel independen terhadap variabel dependen.Uji hipotesis dapat dilakukan dengan melihat hasil dari olah data secara SPSS. Apabila nilai sig lebih kecil < daripada 0,05 atau nilai thitung $>t_{\text {tabel }}$ maka dapat dikatakan terdapat pengaruh variabel X terhadap variabel Y. Sebaliknya apabila nilai sig lebih besar $>$ daripada 0,05 atau nilai $t_{\text {hitung }}<\mathrm{t}_{\text {tabel }}$ maka dapat dikatakan tidak terdapat pengaruh antara variabel $\mathrm{X}$ terhadap variabel $\mathrm{Y}$. 


\section{PEMBAHASAN}

PAD Pemerintah Daerah Berpengaruh Signifikan Terhadap Tingkat Pengungkapan Laporan Keuangan Pemerintah Daerah

Dalam penelitian ini hipotesis pertama yakni pengaruh pendapatan asli daerah berpengaruh signifikan positif terhadap tingkat pengungkapan laporan keuangan pemerintah daerah. Hasil dari pengolahan data secara SPSS dapat dilihat pada tabel 4.11 sebagai berikut:

\section{Tabel 9}

Hasil Pengujian Hipotesis Pertama $\left(\mathrm{H}_{1}\right)$

\begin{tabular}{|c|c|c|c|c|c|}
\hline \multicolumn{6}{|c|}{ Coefficients $^{a}$} \\
\hline \multirow[b]{2}{*}{ Model } & \multicolumn{2}{|c|}{$\begin{array}{l}\text { Unstandardized } \\
\text { Coefficients }\end{array}$} & \multirow{2}{*}{$\begin{array}{c}\text { Standardized } \\
\text { Coefficients } \\
\text { Beta }\end{array}$} & \multirow[b]{2}{*}{$t$} & \multirow[b]{2}{*}{ Sig. } \\
\hline & $\mathrm{B}$ & Std. Error & & & \\
\hline (Constant) & 123.014 & 41.247 & & 2.982 & .004 \\
\hline PAD Pemerintah Daerah & -.025 & .014 & -.398 & 1.879 & .066 \\
\hline
\end{tabular}

a. Dependent Variable: Tingkat Pengungkapan

Sumber: Data hasil olahan SPSS, Tahun 2019

Dari data tabel 4.11 diatas hasil pengujian Uji t-test (hipotesis) diketahui nilai sig untuk pengaruh $\mathrm{X}_{1}$ PAD Pemerintah daerah, terhadap $\mathrm{Y}$ tingkat pengungkapan laporan keuangan pemerintah daerah yakni sebesar 0,066> lebih besar dari 0,05 dan nilai t-hitung $-1.879<$ lebih kecil dari nilai t-tabel 2,00665, sehingga dapat ditarik kesimpulan bahwa hipotesis $\mathbf{H}_{1}$ ditolak, yang berarti tidak terdapat pengaruh antara variabel $\mathrm{X}_{1}$ PAD Pemerintah daerah terhadap variabel $\mathrm{Y}$ tingkat pengungkapan laporan keuangan pemerintah daerah. Hal ini tidak sejalan dengan penelitian yang dilakukan oleh Amalia (2014) yang menyatakan bahwa PAD Pemerintah daerah berpengaruh positif terhadap tingkat pengungkapan laporan keuangan pemerintah daerah.

\section{Ukuran Pemerintah Daerah Berpengaruh Signifikan Terhadap Tingkat Pengungkapan Laporan Keuangan Pemerintah Daerah}

Dalam penelitian ini hipotesis kedua yakni pengaruh ukuran pemerintah daerah berpengaruh signifikan positif terhadap tingkat pengungkapan laporan keuangan pemerintah daerah. Ukuran pemerintah diukur berdasarkan total aset yang dimiliki oleh pemerintah daerah. Hasil dari pengolahan data secara SPSS dapat dilihat pada tabel 4.13 sebagai berikut:

Tabel 10

Hasil Pengujian Hipotesis Kedua $\left(\mathrm{H}_{2}\right)$

\begin{tabular}{|c|c|c|c|c|c|c|}
\hline \multicolumn{7}{|c|}{ Coefficients $^{\mathrm{a}}$} \\
\hline \multirow{2}{*}{\multicolumn{2}{|c|}{ Model }} & \multicolumn{2}{|c|}{$\begin{array}{c}\text { Unstandardized } \\
\text { Coefficients }\end{array}$} & $\begin{array}{c}\text { Standardized } \\
\text { Coefficients }\end{array}$ & \multirow[b]{2}{*}{$\mathrm{t}$} & \multirow[b]{2}{*}{ Sig. } \\
\hline & & $\mathrm{B}$ & Std. Error & Beta & & \\
\hline 1 & (Constant) & 123.014 & 41.247 & & 2.982 & .004 \\
\hline & Ukuran Pemerintah Daerah & .013 & .015 & .163 & .870 & .388 \\
\hline
\end{tabular}
Sumber: Data hasil olahan SPSS, Tahun 2019

Diketahui bahwa dari hasil pengujian hipotesis variabel $\mathrm{X}_{2}$ ukuran pemerintah daerah terhadap variabel Y tingkat pengungkapan laporan keuangan pemerintah daerah, diperoleh hasil 
nilai koefisien sig sebesar $0,388>0,05$ dan nilai t-hitung $0,870<$ dari t-tabel yakni 2,00665. Sehingga dapat diambil kesimpulan bahwa hipotesis $\mathbf{H}_{2}$ ditolak. Namun hasil penelitian ini sejalan dengan penelitian yang dilakukan oleh Lasward et al tahun (2005) yang melakukan penelitian mengenai pengaruh kompetensi politik, Ukuran pemerintah daerah, Leverage, Wealth, Visibilitas Pers, serta tipe pemerintah daerah terhadap International Financial Reporting(IFR).

\section{Tingkat Ketergantungan Pemerintah Daerah Berpengaruh Signifikan Terhadap Tingkat Pengungkapan Laporan Keuangan Pemerintah Daerah}

Dalam penelitian ini hipotesis ketiga yakni pengaruh tingkat ketergantungan pemerintah daerah berpengaruh signifikan positif terhadap tingkat pengungkapan laporan keuangan pemerintah daerah. Tingkat ketergantungan pemerintah daerah dalam penelitian ini di ukur dari jumlah dana alokasi umum dan dana alokasi khusus yang diterima pemerintah daerah. Hasil dari pengolahan data secara SPSS dapat dilihat pada tabel 4.11 sebagai berikut:

Tabel 11

Hasil Pengujian Hipotesis Ketiga (H3)

\begin{tabular}{|c|c|c|c|c|c|c|}
\hline \multicolumn{7}{|c|}{ Coefficients $^{\mathrm{a}}$} \\
\hline & & \multicolumn{2}{|c|}{$\begin{array}{l}\text { Unstandardized } \\
\text { Coefficients }\end{array}$} & $\begin{array}{l}\text { Standardized } \\
\text { Coefficients }\end{array}$ & \multirow[b]{2}{*}{$\mathrm{t}$} & \multirow[b]{2}{*}{ Sig. } \\
\hline \multicolumn{2}{|c|}{ Model } & $\mathrm{B}$ & $\begin{array}{l}\text { Std. } \\
\text { Error }\end{array}$ & Beta & & \\
\hline \multirow[t]{2}{*}{1} & (Constant) & 123.014 & 41.247 & & 2.982 & .004 \\
\hline & Tingkat Ketergantungan Pemerintah Pusat & -.345 & .168 & -.333 & 2.051 & .045 \\
\hline
\end{tabular}
Sumber: Data primer diolah, Tahun 2019

Dari data tabel 4.11 hasil pengujian program SPSS Uji t-test atau pengujian hipotesis dapat diambil kesimpulan bahwa nilai sig koefisien variabel (X3) tingkat ketergantungan pemerintah daerah terhadap tingkat pengungkapan laporan keuangan pemerintah daerah sebesar $0,04<0,05$ dengan nilai t-hitung 2,051> t-tabel 2,0066, sehingga dapat diambil kesimpulan bahwa terdapat pengaruh positif signifikan antara tingkat ketergantungan pemerintah daerah terhadap tingkat pengungkapan laporan keuangan. Maka Hipotesis H3 Diterima.

Hal ini sejalan dengan penelitian yang telah dilakukan sebelumnya oleh Robin dan Austin (1986) yang melakukan penelitian terhadap pemerintah kota, dengan hasil penelitian bahwa tingkat ketergantungan pemerintah kota, berhubungan signifikan positif terhadap tingkat pengungkapan laporan keuangan pemerintah kota. Dengan hasil penelitian yang menyimpulkan bahwa dengan besarnya ketergantungan daerah terhadap pemerintah pusat maka akan semakin besar keinginan pemerintah daerah untuk mengungkapkan informasi keuangan secara lebih serta secara mendetail.

\section{Jumlah Temuan Audit Berpengaruh Signifikan Terhadap Tingkat Pengungkapan Laporan Keuangan Pemerintah Daerah}

Dalam penelitian ini hipotesis ketiga yakni pengaruh jumlah temuan audit berpengaruh signifikan positif terhadap tingkat pengungkapan laporan keuangan pemerintah daerah. Jumlah temuan audit diukur dari laporan kinerja keuangan pemerintah daerah yang diterbitkan oleh badan pemeriksa keuangan terhadap temuan audit dari setiap daerah. Hasil dari pengolahan data secara SPSS dapat dilihat pada tabel 4.11 sebagai berikut: 
Tabel 12

Hasil Pengujian Hipotesis Keempat $\left(\mathbf{H}_{4}\right)$

Coefficients $^{\mathrm{a}}$

\begin{tabular}{|c|c|c|c|c|c|c|}
\hline \multirow[b]{2}{*}{ Model } & & \multicolumn{2}{|c|}{$\begin{array}{l}\text { Unstandardized } \\
\text { Coefficients }\end{array}$} & \multirow{2}{*}{$\begin{array}{c}\begin{array}{c}\text { Standardized } \\
\text { Coefficients }\end{array} \\
\text { Beta } \\
\end{array}$} & \multirow[b]{2}{*}{$\mathrm{t}$} & \multirow[b]{2}{*}{ Sig. } \\
\hline & & B & $\begin{array}{l}\text { Std. } \\
\text { Error }\end{array}$ & & & \\
\hline 1 & (Constant) & 123.014 & 41.247 & & 2.982 & .004 \\
\hline & Temuan Audit & .130 & .123 & .142 & 1.053 & .297 \\
\hline
\end{tabular}

Sumber: Data primer diolah, Tahun 2019

Dari data tabel 4.11 hasil pengujian pada program SPSS diperoleh data bahwa nilai sig koefisien variabel (X4) temuan audit terhadap tingkat pengungkapan laporan keuangan pemerintah daerah sebesar 0,297>0,05 dengan nilai t-hitung 1,053< dari nilai t-tabel 2,0066, sehingga dapat disimpulkan bahwa Hipotesis H4 Ditolak. Hasil penelitian ini tidak sejalan dengan penelitian sebelumnya yang dilakukan oleh Martani dan Liestani (2012) yang menemukan bahwa jumlah temuan audit berhubungan signifikan positif terhadap tingkat pengungkapan laporan keuangan pemerintah daerah.

Dengan hasil bahwa dengan adanya tingkat pengungkapan maka aka nada perbaikan terhadap kualitas laporan keuangan yang disampaikan oleh pemerintah daerah.Penelitian lainnya yang dilakukan oleh Hilmi dan Martani (2012) menemukan bahwa temuan audit tidak berpengaruh terhadap tingkat pengungkapan laporan keuangan pemerintah daerah, sebab temuan audit hanya sebagai dasar untuk melakukan perbaikan terhadap sistem pencatatan laporan keuangan.

\section{KESIMPULAN DAN SARAN Kesimpulan}

Berdasarkan dari hasil pembahasan dan pengolahan data secara statistik maka dapat ditarik beberapa kesimpulan yang terdapat didalam penelitian ini diantaranya adalah sebagai berikut: Penelitian ini membuktikan bahwa tingkat ketergantungan pemerintah daerah berpengaruh terhadap tingkat pengungkapan laporan keuangan pemerintah daerah. Sedangkan pendapatan asli daerah, ukuran pemerintah daerah dan jumlah temuan audit tidak berpengaruh secara signifikan terhadap tingkat pengungkapan laporan keuangan pemerintah daerah.

Dalam penelitian ini juga menunjukkan ketergantungan yang tinggi seluruh kabupaten dan kota yang ada di provinsi sumatera barat terhadap pemerintah pusat, hal ini dikarenakan masih tingginya nilai dana alokasi umum dan dana alokasi khusus yang diterima masing-masing daerah kabupaten dan kota di provinsi sumatera barat. Selain itu tingkat penerimaan pendapatan asli daerah juga masih rendah.

\section{Saran}

Berdasarkan pembahasan dan kesimpulan di atas, maka penulis memberikan saran sebagai Berdasarkan kesimpulan dan keterbatasan penelitian ini, berikut adalah saran yang bisa penulis sampaikan. Bagi Pemerintah daerah kabupaten/ kota agar dapat melakukan pengungkapan laporan keuangan secara menyeluruh dan transparan baik pengungkapan wajib maupun pengungkapan secara sukarela. Sebab dengan tingkat pengungkapan laporan keuangan yang tinggi akan dapat membuat para investor mengerti serta lebih memahami dari laporan keuangan yang ada, agar dapat mempermudah serta sebagai bahan pertimbangan untuk dapat berinvestasi 
di kabupaten maupun kota yang melakukan pengungkapan keuangan secara menyeluruh. Diharapkan penelitian selanjutnya dapat menggunakan variabel independen lain sebagai faktor untuk mengukur tingkat pengungkapan, serta menambah jumlah sampel serta tahun pengamatan penelitian, kemudian dapat menggabungkan penelitian secara kualitatif dan kuantitatif dengan menggunakan triangulasi data.

\section{DAFTAR PUSTAKA}

Agustin, Henri. (2014). Publikasi Dokumen Pengelolaan Anggaran pada Website Pemkab/Pemkot di Propinsi Sumatera Barat. Seminar Nasional Aplikasi Teknologi Informasi (SNATI). Yogyakarta.

Agustin, Henri; Arza, Fefri Indra. (2019). Potrait of Accountability and Transparency in Local Budget Management by the Regional Government in West Sumatera Province, Indonesia: An Anomaly in Digital Era. $4^{\text {th }}$ Padang International Conference on Education, Economics, Business and Accounting (PICEEBA-2 2019). Padang. 154-166.

Andvig, Jens Chr., Odd-Helge Fjeldstad, Inge Amundsen, Tone Sissener \& Tina Søreide. (2001). Corruption A Review of Contemporary Research. Chr. Michelsen Institute Development Studies and Human Rights Report R 2001:7

Angelina, Novita dan Irsitami. (2012). Hubungan Antara Opini Audit Atas Laporan Keuangan Daerah, Pendapatan Asli Daerah (PAD) Dan Dana Alokasi Umum (DAU) Dengan Kinerja Keuangan Daerah Kabupaten/Kota. Jurnal Politeknik Negeri Batam

Budiarta, ketut (2010). Menelusuri Opini Auditor Independen atas LKPD Pemerintah Provinsi Bali. Fakultas Ekonomi. Universitas Udayana

Dwijayanti, Retno dan Rusherlisyanti. (2013). Analisis perbandingan kinerja keuangan pemerintah propinsi seindonesia. Jurnal ekonomi dan bisnis, 12(01).

Halmawati \& Nova, Wati Sri. (2014). Pengaruh Pemahaman Akuntansi, Komitmen Karyawan dan Peran Internal Audit Terhadap Kualitas Laporan Keuangan Pemerintah Daerah (Studi Empiris pada Satuan Kerja Perangkat Daerah di Kabupaten Sijunjung). Jurnal WRA. 2(2), 455-474.

Halim, A. (2004). Manajemen Keuangan Daerah.Yogyakarta: UPP AMP YKPN.

.(2007). Akuntansi SektorPublik: Akuntansi Keuangan Daerah. Edisi Ketiga. Jakarta: Salemba Empat.

Heriningsih, Sucahyo. (2014). Kajian Empiris Tingkat Akuntabilitas Pemerintah Daerah Dan Kinerja Penyelenggara Pemerintah Daerah Terhadap Tingkat Korupsi Pada Kabupaten Dan Kota di Indonesia. Jurnal, 2(2)

Indrarti, Nuansa Mega Okky. (2011). Hubungan antara Opini Audit pada Laporan Keuangan Daerah, Pendapatan Asli Daerah (PAD) dan Dana Alokasi Umum (DAU) terhadap Kinerja Keuangan Daerah. Jurnal Universitas Riau.

Jensen M. C, \&W. Meckling. (1976). Theory of Firm: Managerial Behavior, Agency cost. And Ownership structure. Journal of Financial Economics, 11(4) :5-50

John, Elliott. (2002). The Impact Of Intensive 'Value For Money' Performance Auditing In Educational Systems. Journal of Educational Action Research, 10:3, 499-506.

Liza, W. J., \& Arza, F. I. (2019). Analisis Faktor-Faktor Yang Mempengaruhi Tingkat Pengungkapan Sukarela Laporan Keuangan Pemerintah Daerah. JURNAL EKSPLORASI AKUNTANSI, 1(3), 959-976. 
Novia, Siswita; Arza, Fefri Indra; Agustin, Henri. (2015). Studi Kebutuhan Informasi Pengguna Laporan Keuangan Pemerintah Kota Padang (Studi Empiris pada DPRD dan SKPD Kota Padang). Jurnal WRA, 3(1), 529-548.

Yasmin, Anifa. (2016). Perbandingan kinerja Pemerintah Kabupaten/ Kota yang memperoleh Opini WTP dan Non WTP. Tesis. Universitas Lampung.

, Undang-undang Nomor33 Tahun 2004 Tentang Keuangan Antara Pemerintah Pusat Dan Daerah. 